\title{
Insecurity in Northern Uganda: Are People Being Given the Protection They Deserve?
}

\author{
Cathy Majtenyi
}

\begin{abstract}
The civil war between the Uganda Peoples' Defence Forces (UPDF) and the Lord's Resistance Army (LRA) rages on in Northern Uganda, leaving behind a trail of kidnappings, death and destruction despite measures to protect civilians. Ultimate security for the Acholiand others who live in the North will only come about with an end to the 12-year-old conflict, which would be accomplished by negotiations between the two sides. Unfortunately, misinformation -anda noticeable lack of information, especially from the $L R A$-are major impediments todetermining the war's root causes and who is responsible for the instability. This paper argues that, for a successful end to the war, the government must cease its propaganda war, which is mainly being played out in an uncritical and biased media, and the LRA must be clear about its message. Honest discussion and analytical reporting will greatly facilitate the negotiation process.
\end{abstract}

\section{Précis}

La guerre civile entre les Forces de Défense des Peuples Ougandais (Uganda Peoples' Defence Forces-UPDF) et l'Armée de Résistance des Seigneurs (Lord's Resistance Army-LRA) fait en ce moment rageau nord del'Ouganda. Elle laisse dans son sillage une suite de rapts, de tueries, et de destructions, en dépit des mesures déployées pour protéger les populations civiles. La sécurité intégrale pour les peuples Acholi et les autres peuples qui vivent dans le Nord ne pourra prendreformeque par une conclusion de ce conflit, vieux de douzeans, qui serait le résultat de négociations entreles deux parties. Malheureusement, une

Cathy Majtenyi, a reporter with The Catholic Register, Toronto, is in her second year of the Master of Environmental Studies (MES) program at York University, Toronto. combinaison de désinformation et de non-information, particulièrement dela part du LRA, sont des obstacles majeurs à une compréhension claire des causes originelles de la guerre et del'identitéde la partie responsable de l'instabilité. Le présent article développe une argumentation selon laquelle une fin victorieuse dela guerrepasse parl'interruption de la propagande gouvernementale de guerre diffusées massivement par des médias biaisés et dénués de tout sens critique. Le LRAdoit opter pour un message clair. La discussion honnête et une analyse effective de la situation faciliteront grandement le processus de négociation.

For the past twelve years, Northern Uganda has been embroiled in civil war. The conflict is said to be between the Uganda Peoples' Defence Forces (UPDF) governmentarmy ${ }^{1}$ and the rebel Lord's Resistance Army (LRA) led by Joseph Kony. ${ }^{2}$ This conflicthas wrecked havoc on the population, which is primarily Acholi. Acute poverty, little orno education, the looting and destruction of property, fear, loss of life, ${ }^{3}$ hopelessness, despondence, cultural erosion, starvation, AIDS and an increased infant mortality rate 4 are some of the effects of the conflict. The war has displaced approximately 400,000 people in Gulu and Kitgum Districts. ${ }^{5} \mathrm{Up}$ to 80 per cent of Gulu District's population is displaced. ${ }^{6}$ No one knows exactly how many children have been abducted by the warring forces. A joint UNICEF/World Vision estimates that between 3,000 to 6,000 children aged 10 to 20 years have been abducted over the past two years. ${ }^{7}$ The security situation has deteriorated, especially after a recent spate of rebel attacks. ${ }^{8}$

Toprotectcivilians, formal and informal security measures have been set up over the past few years. Many of the displaced are herded into UPDF-run "protected villages." Others seek refuge in hospitals, church missions and similar institutions. For instance, to cope with an increasing number of people seeking protection, St. Mary's Hospital (Lacor Hospital) in Gulu purchased a plot of land and incorporated it within its walled compound. Hospital administration then drilled boreholes, constructed latrines, put up tents on 2,000 square metres of land, organized teaching for 160 children and distributed food and blankets to about 2,000 people who have settled there permanently. At the peak of conflict-October, 1996, April-May 1997, and October 1997up to 8,000 people sought refuge at Lacor Hospital. ${ }^{9}$ UPDF soldiers are assigned to guard Lacor Hospital and other institutions, protected villages, major roads and towns. Army and local defence unit quarters dot the landscape. To avoid rebel attacks, people sleep in the bush, emerging in the daylight hours. Those with shortwave radios keep abreast of rebel movements and attacks.

Are these security measures adequate? Based on the information cited above, and interviews I conducted while on a recent one-month journalism assignment in Uganda, ${ }^{10}$ the answer is clearly no. Insecurity is a constant threat to the people of Kitgum, Gulu and Lira districts, even for those who live in protected villages. The sheer randomness and brutality of LRA and UPDF attacks lurkin peoples' minds and dictate every facet of life: when and where peoplecan travel; how free they are to gather together day or night; when people can tend their fields. For instance, a woman Imetin Kalongo who is trying to startup a women's pig-rearing project recently wrote of her obstacles:

For the security, the Karamojong [a nearby ethnic group] don't need pigs. They are after the cattle and goats. The rebels don't want [pigs] but they can kill the owners or burn their 
houses. They can do that in the village where there are no soldiers."11

While I travelling around in the month of May, the LRA had hijacked several vehicles, robbing and killing travellers. Seven people were abducted just outside the gate surrounding Lacor Hospital in Gulu during the first night of my stay at the hospital. The UPDF has acted in equally destructive ways. For instance, Ogenga Otunnu writes that in August 1995, a UPDF helicopter gunship killed 210 unarmed civilians and destroyed 100 homes near Kitgum to allegedly stop "a column of LRA." ${ }^{12} \mathrm{~A}$ reportby consultant $R$. Gersony entitled The Anguish of Northern Uganda points out instances where UPDF soldiers beat, raped looted and killed local residents. ${ }^{13}$

No place is safe and schools are especially vulnerable. St. Mary's College in Aboke, Lira district, is a horrific and well-known example. In the early morning hours of Oct. 10, 1996, the LRA rebels smashed their way into the dormitory of the all-girls school, tying up and marching out 139 teenagers. The rebels released most of the girls after headmistress Sr. Rachele Fassera and teacher John Bosco Ocen negotiated with the rebels. Some escaped after being held in captivity for a time. Twenty girls are still missing and presumed dead or held captive in Sudan. I interviewed two girls who managed to escape. They gave harrowing accounts of having to kill and torture other children. One spoke of how rebel leaders would stomp on her chest so badly that, to the present, she still has severe chest pains. Another described her duties as a "wife" to a rebel leader who treated her cruelly.

Among the missing is the daughter of Angelina Acheng Atyam, vice-chair of the Association of Parents Concerned for Children. The 1,311-member group, started by St. Mary's College parents immediately after the abduction, advocates on behalf of all abducted children, both for their release and their reintegration into their former communities. Many of the kidnapped children are rejected by their families and villages once they have escaped because the children may have been forced to kill their neighbours or burn their houses down. Atyam, who was recently honoured by Human Rights Watch, wearily told me that she still washes her missing daughter's clothes from time to time. So many other schoolchildren all across theNorth havemetsimilar fates. Several weeks after my return, a woman who befriended me in Kalongo wrote to tell me her daughter was among $\mathbf{3 8}$ girls kidnapped from St. Charles Lwanga Secondary School on June 20. "I'm in a very deep sorrow," she wrote to me.

The Uganda government's major security measure-posting UPDF soldiers near institutions, towns, protected villages and along highway routeshas had only limited success. UPDF soldiers tend to disappear before rebel attacks and resurface long after attacks. ${ }^{14}$ On the night of the LRA attack on St. Mary's College, for instance, the school was without army protection despite the assurances and promises of three armed units nearby. Fr. Carlos Rodriguez, secretary of the Justice and Peace Commission of Kitgum Diocese, explains it this way, "In recent past occasions people who have been sending reports to military units have sometimes been laughed at or even bullied." ${ }^{15}$ The failure of UPDF soldiers to respond to LRA attacks and the UPDF's seeming indifference to the local population could mean one of two things: they are afraid or ill-equipped to deal with attacks; or there is some form of more direct complicity with the LRA. In any case, the UPDF has failed to protect the local population, causing most Acholi to feel deeply insecure.

This insecurity extends even into protected villages. Allegedly to guard people against rebel incursions, the government rounded up and forced the local population to relocate in these camps. In the process, peoples' property was looted. ${ }^{16}$ Lack of basic health care, physical safety and adequate hygiene characterize these crowded camps. ${ }^{17}$ I visited Awer camp on the outskirts of Gulu town. Mud huts with grass roofs were built closely together and housed a high concentration of people. Crop yields were at an all-time low because of the insecurity and an impending drought. Small children were beginning to exhibit the distended bellies characteristic of malnutrition. People were frightened, apprehensive and anxious about their crops. Most shockingly, I was not offered food or drink, something that is automatically done in Acholiculture. Not to have been served with at least a snack was indicative of extremely hard times. Life at other camps is even harsher. Fr. Rodriguez reports that many people have been abducted and killed at some camps. "You may not have heard a lot about these cases because we are aware that when such incidence happen they are normally not reported in the press or in the radio," he wrote, ${ }^{18}$

The reduced crop yields I observed at Awer camp is a situation echoed in villages and towns all across the North. The war is adding to the reality of impending starvation in Kalongo due to dramatic rainfall fluctuations that have played havoc with the area's planting seasons. ${ }^{19}$ USAID has predicted that rainfall throughout the last six months of 1998 will be "poorly distributed" and that reduced crop yields in 1997 will reduce Uganda's economic growth by three per cent. ${ }^{20}$ It is almost impossible for the average person to make ends meet. One person I interviewed in Kalongo said a family meal consisting of sorghum, sim sim, green vegetablesand fish costs around $\mathrm{SH} 2,3000$ (approximately 700 Uganda shillings is equal to one Canadian dollar). Yet, as a result of the poor harvests and lack of economic opportunity, the monthly income of an average villager is about $\mathrm{SH} 10,000$. Many people turn to alcohol trade and consumption to cope with the war and make ends meet, which has resulted in an increase in alcohol and domestic violence-related admissions to the hospital. ${ }^{21}$ Government and NGO assistance to the area has been hampered or made non-existentby insecurity, drought and other factors. 22

These very difficult economic times, a minimum of assistance, and the fact that the war has continued for so long have ledmany to believe that the government of Yoweri Museveni is against, or indif- 
ferent to, the plight of Northerners. For instance, in its report to a parliamentary committee that is looking to end the Northern war, the Acholi Parliamentary Group has said there is a "lack of political will on the part of government to solve the northern problem. ${ }^{23}$ This perception is in part borne out by observation. The road from Kampala to the Nile River, which divides North and South, is smooth and paved, and lined with milestones, businesses, industries and houses with tin roofs. On the other side of the Nile, the road turns into a sea of potholes, thatched roofs replace tin, there are few businesses and poverty is more visible. The UN's Human Development Report of 1995/96 ranks the North as having the highest infantmortality rate and the lowest per capita income, primary schoolenrolment, access to water and sanitation, and life expectancy rates in Uganda;Central Uganda's per capita income, for instance, is more than double that in the North. ${ }^{24}$ The government "solution" of protected villages has also been roundly criticized. In an interview with the monthly Christian news magazine Leadership, MargaretSsekaggya, chairperson of the Uganda Human Rights Commission, criticized the protected villages, saying that the use of force to control people rather than bringing them into the peace process stalls reconciliation efforts. ${ }^{25}$

Many believe it is this North-South hostility or indifference that is at the root of the current UPDF-LRA conflict, a dynamic that stretches back long before Museveni came to power in 1986. It is beyond thescope of this paper toexplore the historical dimensions of the current conflict. It is suffice to say that identifying the nature of the UPDF-LRA conflict and the individuals or parties responsible for that conflict is crucial for clarifying what protection and assistance measures should be taken and ultimately, the solution to ending this confusing and destructive war. As Ssekaggya said in her Leadership interview, the solution to the war lies in determining its' root cause. "In the North I think Government has even failed to identify the root cause." 26
An historical analysis of the Northern war, unfortunately, does little to shed light on the nature of the contemporary UPDF-LRA conflict and the individuals or parties responsible for that conflict. This is primarily due to the fact that misinformation - and a noticeable lack of information, especially from the LRA — aremajor impediments to determining why the war continues and who is responsible for the instability. Knowing what the LRA wants and why the fighting has continued for so long is a difficult, if not impossible, task for two reasons: the largely-biased media fails to probe deeply into the conflict; and virtually all information about the rebels and the war comes from government sources. The majority of people I interviewed said they did not know what the LRA wanted, why the government was unable to stop the fighting, or even why the fighting was continuing up until the present.

Most international and Ugandan media reports take as their starting point the view that the conflict is a clearcut case of a bizarre group wanting to rule Uganda by the Ten Commandments or someotherdirective and is aiming to do so by terrorizing its own people. It is virtually a given that the Uganda government is doing everything in its power to stop the rebels. ${ }^{27}$ Omara-Otunnu notes that, in reporting on the 1986-87 Holy Spirit Movement led by Alice Lakwena, journalists tended to focus on her personal characteristics at the expense of an analysis of how her movement fit into the politics of Northern Uganda. ${ }^{28}$ The same thing is happening today. An inordinate amount of space is devoted to describing Kony's bizarre behaviour and providing sensationalist details such as how the rebels cut off ears, lips and other atrocities. ${ }^{29}$ While not diminishing the importance of reporting these atrocities, a deeper analysis of why the rebels are attacking - or if, indeed, it is the rebels who are committing these atrocities-and a fuller discussion of the government's responsibilities and performance are sorely needed. Perhaps the fact that virtually every media report has relied on second-hand information about the LRA and its aims impedes this analysis.

One also cannot rely on Ugandan media. While journalists are relatively free to report critically, the government clamps down occasionally on press freedom. ${ }^{30}$ Statistics of the numbers of rebels and people killed come exclusively from the government-there is no independent verification of rebel numbers and deaths. Even the definition of "rebel" is derived from the government. A tragic example from Kitgum illustrates these constraints. ${ }^{31}$ On March 1, 1998, a UPDF mobile unitopened fire on a group of rebels collecting water near the village of Ogole. The March 10 The New Vision reported that 19 rebels had been killed on the spot, while the local Luo newspaper, Rupiny, whose reporter was on the scene immediately after, said that 30 rebels had been killed. A week later, The New Vision of Mar. 18 quoted the Fourth Division commander saying that there were no children killed. Officials from the Justice and Peace Commission of Kitgum Diocese decided to investigate by interviewing local residents and, on March 28, visiting the spot where the killing took place. They found eight bodies_- "their small skulls suggesting they were all children"-tied together with ropes. The "rebels" who were killed turned out to be 30 children who had been captured by the LRA two days before. They were among 80 children tied together with ropes-in full view of the UPDF, which were 10 metres away - sent to collect water for the rebels. ${ }^{32}$

Who, exactly, are the rebels? Several people have told me, in hushed voices, that they cannot tell the difference between LRA rebels and UPDF soldiers. The line between "kidnapped child" and "rebel" is very fine indeed. Each side has employed their specific rhetoric to describe the other. Ugandan President Yoweri Museveni has called those who kidnap children "agents of Sudan government," or "Ugandan bandits linked to the defunct governments of Amin and Obote." ${ }^{33}$ One commonbelief is that the rebels consist of disaffected Acholi afraid of revenge for atrocities committed in earlier regimes. Another 
belief is that the war is an Acholi uprising to overthrow the government. For its part, the LRA has denounced the "many years of lies and vilification that have been peddled in the media about us by Museveni and his supporters" and have "made it abundantly clear that we shall co-operate in any process that is meaningful and can contribute to ending the war that Museveni and theNRA started and have continued to wage against us for the last 10 years." ${ }^{14}$ Who is to be believed?

The government is most often believed, perhaps because of Museveni's reputation as an economic and social "liberator." A frequent observation about Museveni is that he is so much better than Amin or any of those before him. Under Museveni's leadership, Uganda has been touted as "a success story in a continent where such achievements are rare." ${ }^{135}$ Museveni is portrayed as a model of good governance for other African countries, ${ }^{36}$ a "new breed" of African leaders and a "beacon of hope" for Africa. ${ }^{37}$ Uganda itself is rated as one of the "economic miracles" in Africa ${ }^{38}$ by financial institutions such as the World Bank, which have seen the country's gross national product growth rate soar from 0.7 percent between 1965 and 1973 to 5.7 percent between 1987 and 1995 and the inflation rate plummet from 240 percent in 1986-87 to -0.6 percent by June $1993 .{ }^{39}$ Since then, Uganda has registered between six and 10 percent annual economic growth over the past five years. ${ }^{40}$ A commitment to democracy has been said to guide Uganda's political and economic reforms since Museveni took power in $1986 .{ }^{41}$ Since his guerrilla days, Museveni himself has been a strong advocate of "parliamentary democracy, populardemocracy and a decent level of living for every Ugandan" and promised that his government would be an interim one whose main goal would be to restore peace and order. ${ }^{42}$

However, there is a flip side to the glow. Besides the horrors of the war as outlined previously, Ugandans suffer other types of repression and economic hardships. Twelve years afterMuseveni took over, the same government is in power, never having held free-and-fair multiparty elections. The government has increasingly clamped down on press freedoms and freedom of expression. ${ }^{43}$ Amnesty International reports that, in the past year, torture, rape and ill-treatmentby police, soldiers, government militia and others were "common." Police and soldiers were responsible for at least 20 extrajudicial executions and armed opposition groups such as the LRA carried out massive, gross human rights violations. ${ }^{44}$ Uganda's general social and health conditions are dismal. Life expectancy is around 40 years, one of the worst in the world. Two-hundred-andthree out of 1,000 children die before their fifth birthday, and the maternal mortality rate is one of the highest in Africa. ${ }^{45}$ The governmentspends U.S. $\$ 3$ per Ugandan per year on health care. Uganda is U.S. $\$ 3.65$ billion in debt. ${ }^{46}$

As already suggested, little efforthas been directed in serious analysis. The horror of "rebel" atrocities-killing, maiming, kidnapping, child slavery, sexual abuse of children, etc. ${ }^{47}$-has obscured the fundamental issue of how the government responds to this terror and why the war between the UDPF with all its military might and a rag-tag group of mostly children has been dragging on for 12 years. The government spends 60 per cent of its budget on general government, security and defence combined (as compared to 12.6 percent of its budget on social services), ${ }^{48}$ so it stands to reason that it has the resources to end the war.

Tough questions must be posed to, and answered by, both the government and LRA rebels. An identification of the UPDF-LRA war's root cause will only happen if the LRA and the Uganda government come to the table and talkhonestly and in good faith. It is absolutely essential that the LRA be given the opportunity, at the table and in the media, to articulate what it wants and why it is fighting. It is also essential that government propaganda and biased media reporting -especially with respect to the LRA's motives - be more critically examined. ${ }^{49}$ Museveni and his govern- ment tend to use inflammatory language to discredit opponents and leftleaning rhetoric to portray their activities as being progressive. ${ }^{50} \mathrm{As}$ Omara-Otunnu notes:

One of the outstanding successes of the NRA has been the resourceful control of information to cover up political weakness and to attack opponents. Revolutionary rhetoric has been employed to gain legitimacy, groups not enthusiastic about the regime have been characterized as "backward," while critics have been vilified to justified (sic) their elimination or purge..$^{51}$

Stopping the propaganda war is the first step to reconciliation between the LRA and the UPDF, which will ensure the safety of Northern peoples. Protected villages, UPDF patrols, local defence units, hospital compounds and other security measures can only go so far toprotect people; most of theseefforts have failed. Economic development initiatives are useless in a climate of fear and insecurity. A commitment, achieved through honest discussion, from the LRA and the UPDF to end the terrible atrocities is the ultimate protection that Northerners deserve and have not received up until today.

\section{Notes}

1. In 1995, the Uganda government's National Resistance Army (NRA) had been renamed the Uganda Peoples' Defence Forces (UPDF). I will use UPDF to refer to the contemporary army and NRA to describe the army as it was during the first few years of Museveni's rule.

2. I have chosen to focus on the LRA rebel group. There are several rebel groups operating in Uganda, the most notable ones being the West Nile Bank Front (WNBF) and the Allied Democratic Front (ADF).

3. Fr. V. Okot, "Testimony Presented about the War in the North to the Parliamentary Sessional Committee on Defence and Internal Affairs on the 23rd October, 1996," 3.

4. Acholi Parliamentary Group, "Submission to the Parliamentary Committee on Defence and Internal Affairs in Investigating the Northern Rebellion with a View to Bringing It to a Speedy End," 1996, 6-8.

5. USAID, FEWS Uganda Monthly Report, March 1998, 1.

6. USAID, FEWS Uganda Vulnerability Update, February 1998, 1. 
7. UNICEF/World Vision, Shattered Innocence: Testimonies of Children Abduced in Northern Uganda (Kampala: UNICEF Uganda Country Office, 1996), 2.

8. USAID, FEWS Uganda Monthly Report, 1.

9. St. Mary's Newsletter, January 1998, 1.

10. The Comboni Missionaries had hired me for one month to produce several videos highlighting its work across Uganda. I spent two weeks in the North (Lira, Gulu and Kalongo) and two weeks in the South (Kampala and Kasaala). I also wrote a four-part series on life in Uganda for The Catholic Register in Toronto.

11. Personal communication, August 7, 1998.

12. O. Otunnu, "The Path to Genocide in Northern Uganda," Refuge 17, no. 3 (August 1998): 7.

13. Ibid., 8.

14. Acholi Parliamentary Group, "Submission to the Parliamentary Committee on Defence and Internal Affairs," 6; Fr. C. Rodriguez, "Prize Report" (Letter to the Editor), Leadership, no. 371 (May 1998): 3.

15. Fr. C. Rodriguez, "Memorandum of the Catholic Justice and Peace Committee of Kitgum on the Occasion of the Visit of the Pro-Nuncio, The Cardinal, the President of the Uganda Episcopal Conference and the Bishop of Gulu Diocese," May 3, 1998 (posted on AcholiNet on the Internet, May 19, 1998).

16. Ibid.

17. J. Oloka-Onyango, "Uganda's 'Benevolent' Dictatorship," Current History (May 1997): 215.

18. Rodriguez, "Memorandum of the Catholic Justice and Peace Committee of Kitgum."

19. USAID, FEWS Uganda Vulnerability Update, 1.

20 Ibid., 1.

21. C. Majtenyi, "Weather-induced Famine Adds to Uganda's struggle Against Poverty," The Catholic Register, 6 July 1998, 9.

22. J. J. Lule, "Poverty Eradication Initiatives in the North," Leadership, no. 366 (October 1997): 4-5.

23. Acholi Parliamentary Group, "Submission to the Parliamentary Committee on Defence and Internal Affairs," 6.

24. Lule, "Poverty Eradication Initiatives in the North," 4-5.

25. Interview with MargaretSsekaggya, Leadership, no. 366 (October 1997): 6-8.

26. Ibid., 7.

27. Stephen Handelman, "Rescue Saga of Uganda's Girl Soldiers: Rebels Kidnap 8,000 Children in Bloody Bush War," The Toronto Star, 21 December 1997, A1, A20;
Chriatina Spencer, "Waiting for a Miracle," Ottawa Citizen, Sunday, 15 March 1998, A1; "NoChoice but to Kill," Citizen's Weekly, Sunday, 15 March 15 1998, D1 (these two articles indicated a week-long series that looked at various aspects of the war in Northern Uganda).

28. A. Omara-Otunnu, "The Struggle for Democracy in Uganda," The Journal of Modern African Studies 30, no. 3, 1992, 459.

29. Examples of this type of coverage include: "Victims of the LRA. The Children Speak," by Alan Rake, New African, January 1998, 16-18; "The Mission: Face of Terror," by Henry Ochieng, The Monitor, January 20, 1998, 11; "Thou Shall Not Kill," segment on CBS News' 60 Minutes, produced by Andrew Tkach and reported by Christiane Amanpour, 22 March 1998; “No Choice but toKill," by Christina Spencer, Citizen's Weekly, 15 March 1998, D1; "Rescue Saga of Uganda's Girl Soldiers: Rebels Kidnap 8,000 Children in Bloody Bush War," by Stephen Handelman, The Toronto Star, 21 December 1997, A1, A20.

30. S. Dicklitch, "Uganda: A Microcosm of Crisis and Hope in Sub-Saharan Africa," International Journal (Winter 1995-96): 116.

31. Rodriguez, "Prize Report" (Letter to the Editor), 3.

32. Ibid.

33. Y.Museveni, "Letter to His Excellency, the Secretary General of the United Nations," March 7, 1997, 2.

34. Lord's Resistance Movement/Army, "LRA Welcomes London Conference on the Quest for Peace," Press Release, 3 April 1997 (from the Internet: http// www.columbia.edu/ bo $23 / \mathrm{km}$.htm).

35. E. A. Brett, "Neutralising the Use of Force in Uganda: The Role of the Military in Politics," The Journal of Modern African Studies 33, no. 1 (1995): 134.

36. S. Straus, "Uganda: the Cradle of Modern Africa. Rebirth: President Yoweri Museveni Inspired a Generation Committed to Ending Bad Governance," The Globe and Mail, June 21, 1997, A1, A13; see A1.

37. L. Ochieng, "America Chastises Uganda Over Parties," The East African, 25-31 May 1998, 32.

38. Dicklitch,"Uganda: A Microcosm of Crisis and Hope in Sub-Saharan Africa," 123.

39. Ibid., 118.

40. Oloka-Onyango, "Uganda's 'Benevolent' Dictatorship," 214.

41. Brett, "Neutralising the Use of Force in Uganda," 133.

42. Museveni, quoted in Omara-Otunnu, "The Struggle for Democracy in Uganda," 447-48.
43. Dicklitch, "Uganda: A Microcosm of Crisis and Hope in Sub-Saharan Africa," 116; Ochieng, "America Chastises Uganda Over Parties," 32.

44. Amnesty International, "Amnesty International Report 1998" (London: Amnesty International Publications, 1998): 341-43.

45. St. Mary's Hospital (Lacor Hospital) Newsletter, March 1997, 8.

46. M. Mulumba, "Uganda's External Debt," Leadership, no. 371 (May 1998): 15.

47. Amnesty International Uganda, "Breaking God's Commands: The Destruction of Childhood by the Lord's Resistance Army," September 18, 1997, 45 pp.; this abuse is described throughout the report

48. Mulumba, "Uganda's External Debt," 15.

49. For a particularly blatant example of this propaganda, see a profile of Museveni "Uganda: the Cradle of Modern Africa. Rebirth: President Yoweri Museveni Inspired a Generation Committed to Ending Bad Governance" by Scott Straus, The Globe and Mail, 21 June 1997, A1, A13.

50. Acholi Parliamentary Group, "Submission to the Parliamentary Committee on Defence and Internal Affairs," 4; Y. Museveni, "Interview with President Yoweri Museveni" by M. Novicki, and M. Dennis, Africa Report, January-February 1988, 18-21; Museveni, 1997, 2; O. Odongo, "Background Information on the Northern Conflict," (paper presented at a workshop organized by Human Rights Focus in Gulu District Council Hall on November 1-2, 1996), 1-2, 6-8; OlokaOnyango, 1997, 212; Omara-Otunnu, 1992, 447-48, 457-58, 461.

51. Omara-Otunnu, "TheStruggle for Democracy in Uganda," 461.

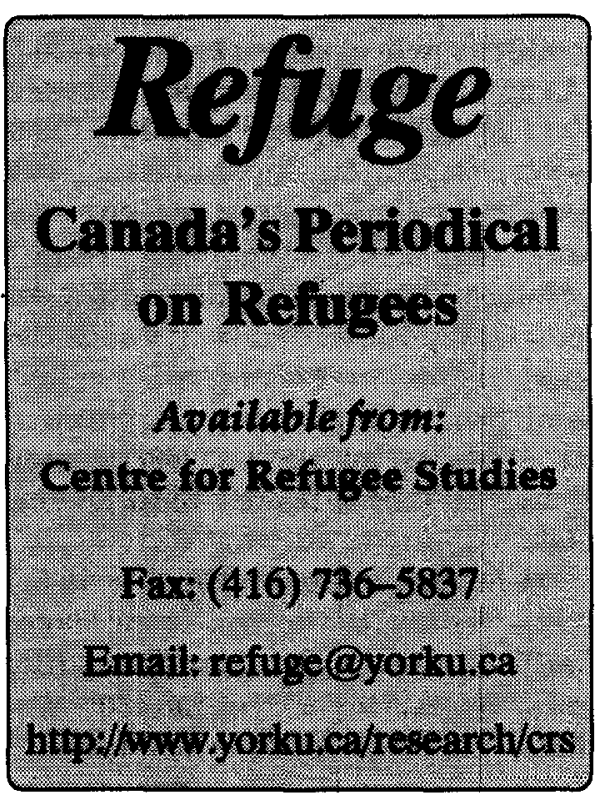

